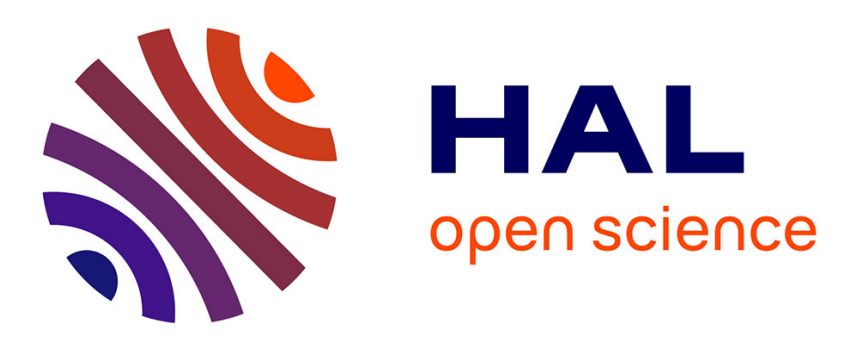

\title{
Quantitative measurement of permeabilization of living cells by terahertz attenuated total reflection
}

\author{
Marianne Grognot, Guilhem Gallot
}

\section{To cite this version:}

Marianne Grognot, Guilhem Gallot. Quantitative measurement of permeabilization of living cells by terahertz attenuated total reflection. Applied Physics Letters, 2015, 107 (10), pp.103702. 10.1063/1.4930168. hal-01222843

HAL Id: hal-01222843

https://hal-polytechnique.archives-ouvertes.fr/hal-01222843

Submitted on 30 Oct 2015

HAL is a multi-disciplinary open access archive for the deposit and dissemination of scientific research documents, whether they are published or not. The documents may come from teaching and research institutions in France or abroad, or from public or private research centers.
L'archive ouverte pluridisciplinaire HAL, est destinée au dépôt et à la diffusion de documents scientifiques de niveau recherche, publiés ou non, émanant des établissements d'enseignement et de recherche français ou étrangers, des laboratoires publics ou privés. 


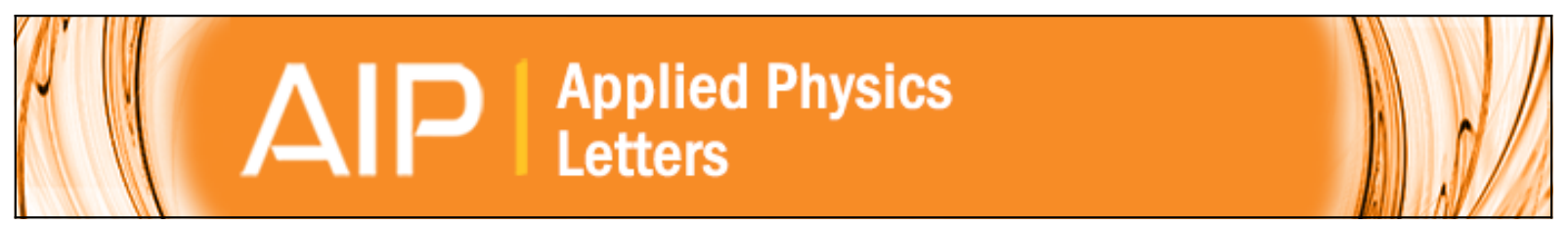

\section{Quantitative measurement of permeabilization of living cells by terahertz attenuated total reflection}

Marianne Grognot and Guilhem Gallot

Citation: Applied Physics Letters 107, 103702 (2015); doi: 10.1063/1.4930168

View online: http://dx.doi.org/10.1063/1.4930168

View Table of Contents: http://scitation.aip.org/content/aip/journal/apl/107/10?ver=pdfcov

Published by the AIP Publishing

\section{Articles you may be interested in}

In vivo, label-free, three-dimensional quantitative imaging of liver surface using multi-photon microscopy Appl. Phys. Lett. 105, 023701 (2014); 10.1063/1.4890593

Early detection of cell activation events by means of attenuated total reflection Fourier transform infrared spectroscopy

Appl. Phys. Lett. 104, 243705 (2014); 10.1063/1.4885081

Microplate-compatible total internal reflection fluorescence microscopy for receptor pharmacology

Appl. Phys. Lett. 102, 193702 (2013); 10.1063/1.4805041

Flow bioreactor design for quantitative measurements over endothelial cells using micro-particle image velocimetry

Rev. Sci. Instrum. 84, 045109 (2013); 10.1063/1.4802681

Method for measuring the three-dimensional distribution of a fluorescent dye in a cell membrane

Appl. Phys. Lett. 90, 021110 (2007); 10.1063/1.2428457

\section{AIP $\left.\right|_{\text {APL Photonics }}$}

APL Photonics is pleased to announce Benjamin Eggleton as its Editor-in-Chief

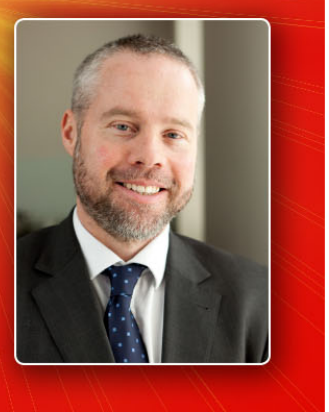




\title{
Quantitative measurement of permeabilization of living cells by terahertz attenuated total reflection
}

\author{
Marianne Grognot and Guilhem Gallot ${ }^{\text {a) }}$ \\ Laboratoire Optique et Biosciences, Ecole Polytechnique, CNRS UMR7645, 91128 Palaiseau, France \\ and INSERM U1182, 91128 Palaiseau, France
}

(Received 1 July 2015; accepted 25 August 2015; published online 10 September 2015)

\begin{abstract}
Using Attenuated Total Reflection imaging technique in the terahertz domain, we demonstrate noninvasive, non-staining real time measurements of cytoplasm leakage during permeabilization of epithelial cells by saponin. The terahertz signal is mostly sensitive to the intracellular protein concentration in the cells, in a very good agreement with standard bicinchoninic acid protein measurements. It opens the way to in situ real time dynamics of protein content and permeabilization in live cells. C 2015 AIP Publishing LLC. [http://dx.doi.org/10.1063/1.4930168]
\end{abstract}

Reversible permeabilization of live cells is a complex and increasingly addressed issue, whether it is for medical application, ${ }^{1,2}$ or in laboratory research protocols, where a constant effort is made to reach more realistic investigation conditions in biological systems. ${ }^{3-5}$ Permeabilization is defined as the increase of molecule transfers through the cell membrane, often using surfactants. Applications cover anticancer drugs or imaging marker delivery, gene therapy, etc. Besides complex viral vectors that rise potential immune issues, ${ }^{6}$ delivery of biomolecules can be done mechanically or chemically. ${ }^{7}$ Reversible permeabilization is mostly obtained by techniques creating pores into the membrane, the most common ones being electroporation, ${ }^{8}$ non-ionic detergent, ${ }^{9}$ and pore-forming toxins. ${ }^{10}$ The terahertz domain exhibits many advantages. It is directly sensitive to ions and proteins contrary to the visible domain, it does not suffer from very high absorption as the infrared, and it offers better spatial resolution than the hyper-frequency domain. ${ }^{11}$ The terahertz region has been shown to have potential in biomedical applications, but strong experimental limitations had long kept the study of biological objects down to the single purified molecule, simplified and/or pre-treated biological structures. ${ }^{12-14}$ Recent works demonstrated the possibility to spectroscopically investigate more complex systems as cells ${ }^{15,16}$ and even accessible tissues ${ }^{17,18}$ or small organs. ${ }^{19}$ By using a terahertz Attenuated Total Reflection (THz-ATR) imaging device designed for biological samples, we demonstrate here the possibility to use $\mathrm{THz}$ sensitivity in following permeabilization dynamics of a live cells layer in real time, without any marker or sample preparation. The origin of the terahertz contrast is also investigated.

THz-ATR makes use of the evanescent wave at the back of a prism under total internal reflection, through the object under study. The decay of the evanescent wave ranges from 20 to $30 \mu \mathrm{m}$, depending on the prism angle and on the refractive index of the object. ${ }^{20}$ We consider a thin layer of cells and the surrounding solution in this inhomogeneous evanescent wave. Providing that the thickness of the cell layer matches the decay depth of the evanescent

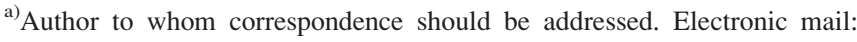
Guilhem.Gallot@polytechnique.edu.
}

wave, the reflected terahertz wave is mostly modified by the terahertz dielectric properties of the cell layer in contact with the upper side of the prism. The extracellular solution above the cell layer only weakly affects the terahertz signal. The best signal is obtained for an evanescent decay smaller than the cell layer thickness, and for a compact cell layer. If not, the signal remains proportional to the cell content, but its amplitude decreases. The resulting reflected terahertz signal is then mostly correlated to the cell content. Therefore, a content leakage from the cell to the surrounding solution will be easily detected by the change of the cell content.

The THz-ATR device (Fig. 1) is a very transparent highresistivity silicon (HR-Si) isosceles prism $(R>10 \Omega \cdot \mathrm{cm}$, $\mathrm{n}=3.42$ ) with a base angle of $42^{\circ} .{ }^{20}$ This incident angle provides internal reflection conditions. For imaging purpose, the silicon prism is topped with a $3 \mathrm{~mm}$ thick HR-Si patch on which the samples are placed and which can be precisely mechanically moved. Plenty of space is available above the prism for biological samples and related controls. The $\mathrm{THz}$ signal is generated by a classical THz time-domain spectroscopy (THz-TDS) setup, ${ }^{21}$ composed of a GaAs photoconductive transmitter lit by a $12 \mathrm{fs}-76 \mathrm{MHz}$-fs titanium-sapphire

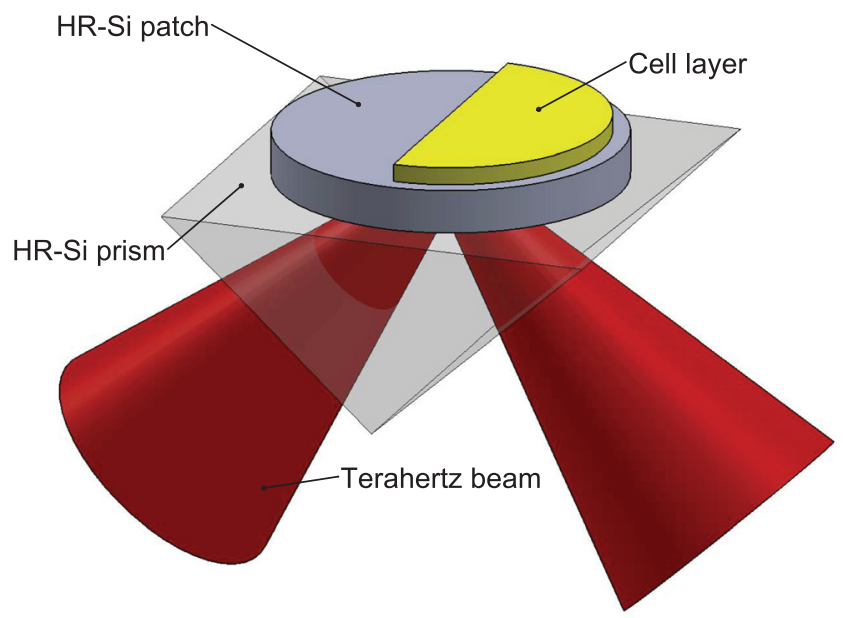

FIG. 1. The THz-ATR device is made of a high resistivity silicon (HR-Si) isosceles prism topped by a moving HR-Si patch. Epithelial cells are directly grown on the HR-Si patch. 
laser that generates an almost linearly polarized sub-single cycle THz pulse, centered around $1 \mathrm{THz}$ and extending up to $4 \mathrm{THz}$. The pulse is detected by a low temperature grown GaAs photoconductive detector. A delay line between the emitter and detector $\mathrm{THz}$ chips allows to measure the $\mathrm{THz}$ electric field at controlled delays $t$, allowing either spectroscopic or amplitude measurements.

The cells being imaged in the THz-ATR device are epithelial Madine-Darby Canine Kidney (MDCK) cells. MDCK cells are a permanent cell line derived from dog kidney. They form a typical cuboidal single layer epithelium when grown to confluence, where they display a height of 10 to $12 \mu \mathrm{m},{ }^{22}$ matching well the evanescent wave decay. This single cell layer covers the silicon patch in contact with it. They are widely used as a model cell line for studies on epithelial polarization and transport, mechanisms of infection, junctions, permeability properties of early drug discovery compounds, etc. ${ }^{23}$ MDCK cells are maintained in DMEM (Dulbecco's Modified Eagle Medium) supplemented with $10 \%$ fetal calf serum, $1 \%$ penicillin-streptomycin at $37^{\circ} \mathrm{C}$ and $5 \% \mathrm{CO}_{2}$. Cells are harvested with trypsin-EDTA, plated on Si-patch in culture medium and grown until confluence. Half of the layer is kept on the patch, and the other half is scratched free as a reference. Before each experiment, the patch is washed with HBSS (Hank's Balanced Salt Solution) and let reach room temperature $\left(21^{\circ} \mathrm{C}\right)$ in $3 \mathrm{ml}$ of a solution of HBSS containing $10 \mathrm{mM}$ of HEPES as a buffering agent. Since the patch diameter is $36 \mathrm{~mm}$, the cells are covered by $3 \mathrm{~mm}$ of solution. Experiments refer to time $T$ following a perturbation applied to the cells at $T=0$.

Acquisitions are made with silicon patch half covered with a cell layer, half cell-free occupied by the cell medium as in Fig. 1. Peak Amplitude (PA) of the THz pulse is chosen as it demonstrates the strongest modification between cells and free patch surface. Comparison between visible and terahertz images is given in Fig. 2(a). We define a relative $\Delta_{r e l}$ and normalized $\Delta$ experimental contrasts in Eqs. (1) and (2), respectively. $\Delta_{\text {rel }}$ stands for the direct ratio of peak amplitude (PA) variations, and $\Delta$ for its normalized value with respect to $T=0$ value, as follows:

$$
\begin{gathered}
\Delta_{r e l}=\frac{P A_{x}-P A_{r e f}}{P A_{r e f}}, \\
\Delta=\frac{\Delta_{r e l}(T)}{\Delta_{r e l}(T=0)},
\end{gathered}
$$

where $P A_{x}$ and $P A_{\text {ref }}$ are defined in Fig. 2(b) inset as the peak amplitudes at a given $x$ position and in the empty zone, respectively. For each position, the amplitude peak value is determined by the acquisition of 8 different temporal points $t$ by slightly changing the delay line of the THz-TDS setup, each one necessitating a $30 \mathrm{~ms}$ set up time (Fig. 2(b), inset). A single PA point is therefore obtained in about $0.25 \mathrm{~s}$. Several temporal points are needed to measure the maximum amplitude, in spite of sampling or time shift due to a change of the dielectric constant of the cells. The cell layers typically display a 6 to $8 \%$ peak-amplitude relative contrast $\Delta_{\text {rel }}$ compared to the medium alone. Typical curves along a single line are presented in Fig. 2(b).
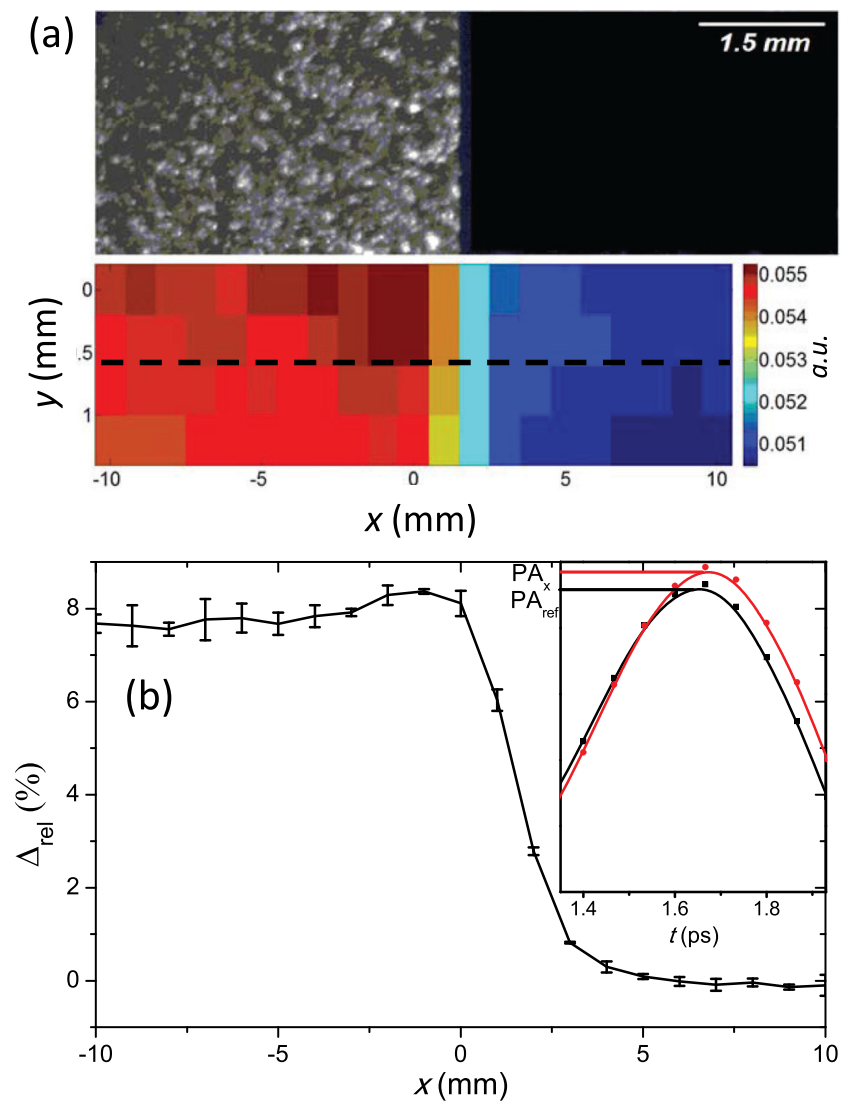

FIG. 2. (a) Optical (top) and THz-ATR (bottom) images with MDCK epithelial cell monolayer (left) compared without cells (right). Cross-section (dotted black line) is displayed below. (b) Mean of 3 consecutive $45 \mathrm{~s}$ crosssections. The inset is an example of two pulse peaks taken in cell (red) or medium (black) zones, versus the delay $t$ of the THz-TDS setup.

In order to confirm that the contrast indeed comes from the cell content, a strong detergent (Triton-X100, Sigma Aldrich) is added at a high concentration known to quickly kill the cells by solubilizing their membrane. $\Delta_{\text {rel }}$ drops from around $8 \%$ to less than $1 \%$ due to a phantom of the cell layer still present at the end, so most of the contrast comes from the cell content. When the cell layer is simply removed by scrubbing and renewing the medium, the contrast totally disappears. The origin of the observed contrast is now investigated.

Saponins at high concentration are more commonly used in immunocytochemistry to permeabilize membranes of different kind of fixed cells, but have also been reported to permeabilize live cell plasma membrane at low concentration ${ }^{24,25}$ and in a reversible way. ${ }^{26,27}$ It is a nonionic detergent that creates non-specific pores in cell membrane, most probably by binding with the cholesterol within the lipid components of the cell membrane.$^{28}$ It mostly triggers protein and ion transfers through the membrane. The concentration of Saponin (Sigma Aldrich) targets $75 \mu \mathrm{g} / \mathrm{ml}$. After saponin is added at $21^{\circ} \mathrm{C}$, a delay plateau is observed on $\Delta$ (Eq. (2)) during several minutes, then $\Delta$ decreases (Fig. 3, red circles). We believe the observed decrease in $\Delta$ sensitively reflects that of the intracellular protein concentration in the cells. Such a delay has already been reported during the time course of saponininduced release of LDH (Lactate DeHydrogenase), a marker for soluble cytosolic proteins, suggested to reflect the time required for the formation of the plasma membrane lesions. ${ }^{25}$ 


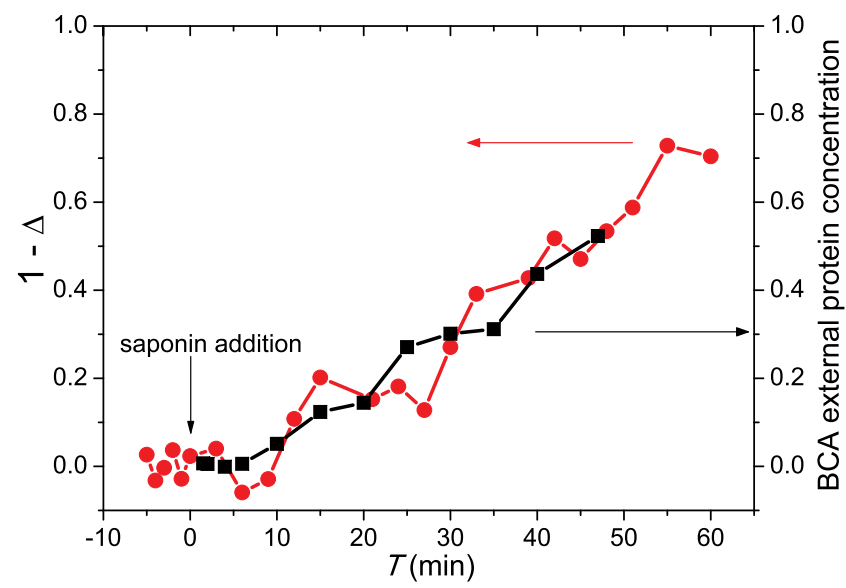

FIG. 3. Normalized extracellular protein concentration (black squares) and normalized $\mathrm{THz}$ contrast $(1-\Delta$, red rounds) after addition of $75 \mu \mathrm{g} / \mathrm{ml}$ of saponin at $21^{\circ} \mathrm{C}$, at time $T=0$.

Different toxins known to disturb the ionic asymmetric equilibrium were tested, but none of them showed a significant impact on $\Delta$, showing that ions do not seem to play a major role here.

To quantify protein leakage during permeabilization, a bicinchoninic acid (BCA) Protein Assay kit (Life Technologies) was used. This assay is a standard colorimetric assay, determining protein concentration, well-suited for heterogeneous protein solutions even in the presence of detergents and various cell compounds. ${ }^{29}$ In order to stay in the detection range, the assay was made on very small extracellular volumes ( $200 \mu \mathrm{l}$, in 24 wells plates). An assay requires an approximate 2 to $3 \mathrm{~h}$ for calibration and sample preparation, incubation, spectrometer reading, and analyzing.

A BCA was made under the same concentration of saponin, and the normalized result is compared to $1-\Delta$ in Fig. 3. $\Delta$ measures the cell content, so $1-\Delta$ measures the extracellular solution content. A positive control at the end of a $\mathrm{THz}$ experiment ensures that the extracellular protein concentration indeed rises as observed in the BCA made in 24-wells plate. Normalized external protein concentration and $1-\Delta$ show a very good agreement. Visible camera images do not show any cell detachment, even under gentle medium movements, up to $40 \mathrm{~min}$ where the borders seem to start to detach, but without any detachment in the central observed region. Plated confluent cells were also observed under microscope after addition of $80 \mu \mathrm{g} / \mathrm{ml}$ saponin and showed no detachment before $30 \mathrm{~min}$ and very little morphological change. This is an important verification as the sample is probed only if lying in the evanescent wave zone.

We now present a simple simulation approach comparing the respective importance of ion and protein contributions to the $\mathrm{THz}$ contrast. The theoretical contrast $\Delta_{t h}$ of simple biological solutions with known dielectric constant is calculated by a 3-level (HR-Si, cells, and surrounding medium) model based on Fresnel equations, and compared to measured contrasts $\left(\Delta_{r e l}\right)$. Common reference for contrast is distilled water except for $\Delta_{\text {rel }}$ of epithelial cell where HBSS + HEPES is used. Results are shown in Table I. All errors in $\Delta_{\text {rel }}$ are within $\pm 0.3 \%$. For epithelial cells, $\Delta_{t h}$ around $6 \%$ is obtained between a thin $(12 \mu \mathrm{m})$ cell layer compared to distilled water,
TABLE I. Theoretical and experimental contributions to contrasts of simple ion and protein solutions.

\begin{tabular}{lcc}
\hline \hline & $\Delta_{r e l}$ & $\Delta_{t h}$ \\
\hline HBSS + HEPES & $-1.3 \%$ & $-1.4 \%$ \\
KCl $(100 \mathrm{mM})$ & $-1 \%$ & $-1.1 \%$ \\
Albumin $(50 \mathrm{~g} / \mathrm{l})$ & $2.2 \%$ & No data \\
Epithelial cells & 6 to $8 \%$ & $6 \%$ (Ref. 16) \\
\hline \hline
\end{tabular}

based on theoretical measured dielectric constant index at $1 \mathrm{THz}$ on HeLa cells. ${ }^{16}$ This is consistent with our observed contrast around 6 to $8 \%$ between MDCK and HBSS + HEPES solution, as this solution is expected to add an approximate $1 \%$ contrast compared to distilled water.

Using this model, and confirming the order of magnitude observed with a simple ionic solution of $\mathrm{KCl}$, we determined that the ionic asymmetric repartition between inside and outside the cell generates a maximum $-1 \%$ relative contrast. Unlike the small contrasts obtained by physiological ionic solutions, albumin (medium sized protein, $44 \mathrm{kDa}$ ) shows a positive $\Delta_{r e l}$ around $2.2 \%$ at a concentration corresponding to approximately only a quarter of the mean protein concentration inside MDCK. ${ }^{30}$ Therefore, modeling and simple
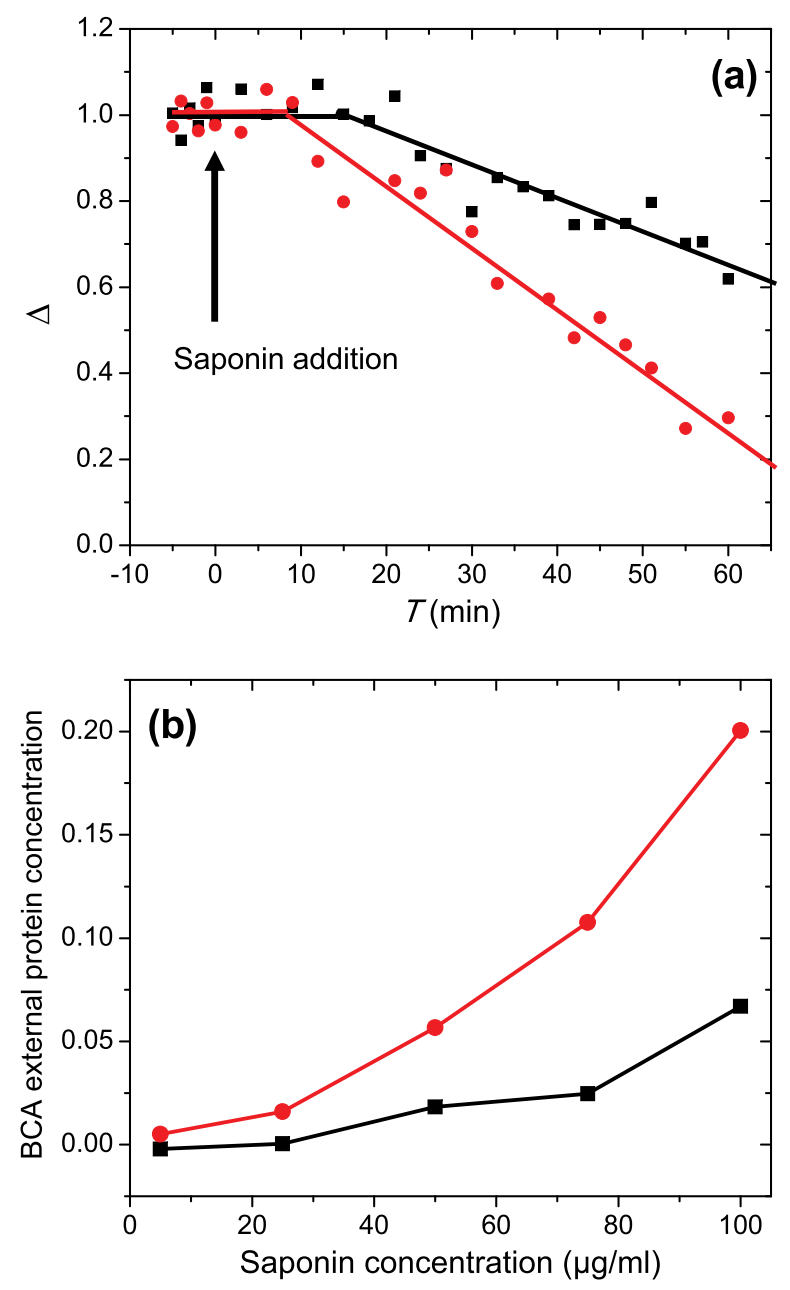

FIG. 4. (a) $\Delta$ variation for two different saponin concentrations introduced at $T=0 \mathrm{~min}$, for $50 \mu \mathrm{g} / \mathrm{ml}$ (black squares) and $75 \mu \mathrm{g} / \mathrm{ml}$ (red rounds). (b) BCA normalized results at two different time $(T=5 \mathrm{~min}$, squares, and $22 \mathrm{~min}$, rounds) in the [5-100] $\mu \mathrm{g} / \mathrm{ml}$ saponin range. 
experimental values on ions and proteins seem to consolidate the assumption that the contrast mainly originates from internal protein concentrations.

A first example of differential permeabilization dynamics depending on the saponin concentration is shown in Fig. 4(a) for saponin at 50 and $75 \mu \mathrm{g} / \mathrm{ml}$. Both curves exhibit first a plateau, then a decrease of the contrast. The dynamics of the contrast is about twice as fast at $75 \mu \mathrm{g} / \mathrm{ml}$ saponin as at $50 \mu \mathrm{g} / \mathrm{ml}$, and the plateau is twice as long at $50 \mu \mathrm{g} / \mathrm{ml}$. Those observations are in good agreement with a BCA done at two different times for 5 different saponin concentrations (Fig. 4(b)). The BCA demonstrates a very sharp dependency of the permeabilization to the saponin concentration in the [22-100] $\mu \mathrm{g} / \mathrm{ml}$ range, consistent with the previously reported results. $^{25}$ At $T=5 \mathrm{~min}, 50$ and $75 \mu \mathrm{g} / \mathrm{ml}$ do not have significantly different effects on the normalized external protein concentration (Fig. 4(b), black square). On the contrary, at $T=22 \mathrm{~min}$, the external concentration in both case has increased significantly meaning they are no more in the plateau region (Fig. 4(b), red circle).

In conclusion, this work demonstrates that THz-ATR measurements allow noninvasive in situ real time study of biological samples in physiological conditions, without staining or labeling. Cell layers of $10 \mu \mathrm{m}$ thickness can be easily investigated, as it is of the same extension as the probing evanescent field. The contrast observed between cells and the surrounding medium is understood as mainly coming from the intracellular protein composition of cells. Its variations give access to the dynamics of cytoplasm leakage when cells are permeabilized, which is of great interest when it comes to efficiently but reversibly permeabilize a cell layer. This method has many advantages over the classical BCA method for following protein leakage. It is noninvasive, so a whole dynamic can be done on the same layer. It directly probes the inside cell composition instead of the extracellular volume, so no extracellular volume restriction or control are needed. Also, a THz measurement is much faster than BCA, allowing real time measurements without calibration requirements.

The authors thank Lluis Mir and his colleagues from Institut Gustave-Roussy, Villejuif, France, for fruitful discussions on MDCK cells and electroporation.
${ }^{1}$ J. Gehl, Acta Physiol. Scand. 177, 437 (2003).

${ }^{2}$ D. G. Spiller, R. V. Giles, J. Grzybowski, D. M. Tidd, and R. E. Clark, Blood 91, 4738 (1998).

${ }^{3}$ U. Schnell, F. Dijk, K. A. Sjollema, and B. N. G. Giepmans, Nat. Methods 9, 152 (2012).

${ }^{4}$ K. Lymperopoulos, A. Kiel, A. Seefeld, K. Stöhr, and D.-P. Herten, ChemPhysChem 11, 43 (2010).

${ }^{5}$ J. B. Delehanty, H. Mattoussi, and I. L. Medintz, Anal. Bioanal. Chem. 393, 1091 (2009).

${ }^{6}$ C. E. Thomas, A. Ehrhardt, and M. A. Kay, Nat. Rev. Genet. 4, 346 (2003).

${ }^{7}$ I. Hapala, Crit. Rev. Biotechnol. 17, 105 (1997).

${ }^{8}$ B. Al-Sakere, F. André, C. Bernat, E. Connault, P. Opolon, R. V. Davalos, B. Rubinsky, and L. M. Mir, PLoS ONE 2, e1135 (2007).

${ }^{9}$ D. Koley and A. J. Bard, Proc. Natl. Acad. Sci. USA 107, 16783 (2010).

${ }^{10}$ I. Walev, S. C. Bhakdi, F. Hofmann, N. Djonder, A. Valeva, K. Aktories, and S. Bhakdi, Proc. Natl. Acad. Sci. USA 98, 3185 (2001).

${ }^{11}$ G. J. Wilmink and J. E. Grundt, J. Infrared Milli. TeraHz. waves 32, 1074 (2011).

${ }^{12}$ D. F. Plusquellic, K. Siegrist, E. J. Heilweil, and O. Esenturk, ChemPhysChem 8, 2412 (2007).

${ }^{13}$ P. Jepsen, D. Cooke, and M. Koch, Laser Photon. Rev. 5, 124 (2011).

${ }^{14}$ M. Nagai, H. Yada, T. Arikawa, and K. Tanaka, Int. J. Infrared Milli. Waves 27, 505 (2006).

${ }^{15}$ J.-B. Masson, M.-P. Sauviat, J.-L. Martin, and G. Gallot, Proc. Natl. Acad. Sci. USA 103, 4808 (2006).

${ }^{16}$ K. Shiraga, Y. Ogawa, T. Suzuki, N. Kondo, A. Irisawa, and M. Imamura, J. Infrared Milli. TeraHz Waves 35, 493 (2014).

${ }^{17}$ C. Yu, S. Fan, Y. Sun, and E. Pickwell-MacPherson, Quant. Imaging Med. Surg. 2, 33 (2012).

${ }^{18}$ R. M. Woodward, B. E. Cole, V. P. Wallace, R. J. Pye, D. D. Arnone, E. H. Linfield, and M. Pepper, Phys. Med. Biol. 47, 3853 (2002).

${ }^{19}$ J.-B. Masson, M.-P. Sauviat, and G. Gallot, Appl. Phys. Lett. 89, 153904 (2006).

${ }^{20}$ A. Wojdyla and G. Gallot, Opt. Lett. 38, 112 (2013).

${ }^{21}$ A. Podzorov and G. Gallot, Appl. Opt. 47, 3254 (2008).

${ }^{22}$ A. Puliafito, L. Hufnagel, P. Neveu, S. Streichan, A. Sigal, D. K. Fygenson, and B. I. Shraiman, Proc. Natl. Acad. Sci. USA 109, 739 (2012).

${ }^{23}$ F. Lang and M. Paulmichl, Kidney Int. 48, 1200 (1995).

${ }^{24}$ K. Medepalli, B. W. Alphenaar, R. S. Keynton, and P. Sethu, Nanotechnology 24, 205101 (2013).

${ }^{25}$ M. Wassler, I. Jonasson, R. Persson, and E. Fries, Biochem. J. 247, 407 (1987).

${ }^{26}$ E. Weibull, S. Matsui, M. Sakai, H. A. Svahn, and T. Ohashi, Biomicrofluidics 7, 064115 (2013).

${ }^{27}$ Z. Wang, M.-C. Kim, M. Marquez, and T. Thorsen, Lab Chip 7, 740 (2007).

${ }^{28}$ G. Francis, Z. Kerem, H. P. S. Makkar, and K. Becker, Br. J. Nutr. 88, 587 (2002).

${ }^{29}$ J. M. Walker, in Basic Protein and Peptide Protocols, edited by J. M. Walker (Humana Press, 1994), Vol. 32, pp. 5-8.

${ }^{30}$ S. Erlinger and M. H. Saier, Jr., In Vitro 18, 196 (1982). 